\title{
Pull the Trigger, it Fires: The Critical Role of Insulin-Stimulated Caveolin-1 Tyrosine 14 Phosphorylation in Regulation of Insulin Trans-Endothelial Transport
}

\section{Hong Wang*}

Department of Internal Medicine, University of Virginia Health System, Charlottesville, VA 22908, USA

*Corresponding author: Hong Wang, Division of Endocrinology and Metabolism, Department of Internal Medicine, Hong Wang University of Virginia Health System 450 Ray C. Hunt Drive, Box 801410, Charlottesville, VA 22908, USA, Tel: +434-982-0173; Fax: 434-924-1284; E-mail: Hw8t@virginia.edu

Rec date: Mar 23, 2015, Acc date: Mar 25, 2015, Pub date: Mar 27, 2015

Copyright: @ 2015 Wang $\mathrm{H}$. This is an open-access article distributed under the terms of the Creative Commons Attribution License, which permits unrestricted use, distribution, and reproduction in any medium, provided the original author and source are credited.

\section{Editorial}

In order for insulin to exert its biological actions on target cells in peripheral tissues like muscle and adipose tissues, Insulin must pass through the endothelial barrier into the interstitium.Insulin's transendothelial transport (TET), particularly in muscle where capillaries are lined by a continuous endothelium, determines tissue insulin levels, and thereby critically determines insulin's metabolic effects [1-6]. This process is significantly impaired in insulin resistance states such as obesity and type 2 diabetes [2,7-9]. Current evidence obtained by us and others indicate that insulin TET is transcellular process and mediated by transporting caveolae that contain or associate with multiple structural and signaling molecules including the insulin receptor (IR), IGF-1receptor, caveolin-1, dynamin-2, actin filaments and eNOS [10-18]. Among these components, caveolae and its key structural protein caveolin-1 have been shown to serve as the center to organize the molecular transcytotic machinery mediating insulin TET [13]. We have demonstrated that insulin, through its signaling pathways in the endothelium, facilitates its own movement across the endothelial cells [15]. Very recently, we reported that eNOS and its activity play a critical role in regulation of insulin uptake and TET as inhibition of eNOS activity completely eliminates endothelial insulin uptake and TET [16]. Next critical question we would ask is how insulin intracellular signaling stimulates and coordinates the assembling of the molecular machinery for insulin trans-endothelial transport? A study just published by us has provided a clue to this puzzle, i.e. insulin stimulated caveolin-1 tyrosine 14 phosphorylation severs a trigger to possibly initiate insulin TET [19].

Caveolae are abundant in microvasculature [20] and represent $>95 \%$ of the endothelial cell vesicles [21]. Caveolin-1 is the main structural unit and biological marker of endothelial caveolae. Caveolin-1 is required for the formation of caveolae in vascular endothelium as either targeted deletion of the gene for caveolin-1 (Cav-1-/-) [22] or knockdown of caveolin-1 expression using specific siRNA [23] results in the loss of caveolae.In contrast, expression of exogenous caveolin-1 in lymphocytes (which are normally devoid of caveolae) induces the de novo formation of caveolae, and the level of caveolin-1 expression directly correlated to the number of caveolae [24]. Early studies have shown that binding of protein macromolecules to their receptors on the cell surface induced a caveolae-mediated endocytosis whereby caveolae, as a transporting carrier, can efficiently mediate the transcellular transport of a variety of plasma proteins through the endothelial barrier [25-27]. While it would seem desirable to examine the role of caveolin-1 in mediating insulin TET using caveolin-1 (-/-) knockout mice, lack of caveolin-1 has been shown to induce a paracellular leak of macromolecules attributed to the loss of the tonic caveolin-1 inhibition of eNOS activity that restrains paracellular pathway permeability [28,29]. Alternatively, we have observed that siRNA-mediated knockdown of caveolin-1 expression in vascular endothelial cells reduced FITC-insulin uptake by $67 \%$, whereas over-expression of wild-type caveolin-1 increased insulin uptake [13]. Consistently, in the same study, we also observed that aortic endothelial cells from caveolin-1 (-/-) knockout mice failed to take up FITC-insulin [13]. Moreover, caveolae are enriched in insulin receptors [30] and are known to concentrate and organize a variety of signaling molecules at the plasma membrane through the caveolin-1 scaffolding domain to facilitate intracellular signaling transduction [31]. Knockdown of caveolin-1 significantly reduced both insulin receptor protein level and insulin-stimulated Akt1 phosphorylation [13]. On the other hand, early studies have demonstrated that caveolin-1 is a major tyrosine-phosphorylated substrate of Src kinase [32-34]. There are total 9 tyrosine residues in the caveolin-1 molecule but only Tyr14 undergoes phosphorylation by cSrc kinase [34]. In 3T3L1 adipocytes insulin stimulates caveolin-1 phosphorylation at Try14, which is dramatically inhibited by inhibition of Src kinase [35]. However, blocking direct interaction between caveolin-1 and the insulin receptor by mutation of caveolin-1 scaffolding domain prevents insulin-stimulated caveolin-1 Tyr14 phosphorylation in adipocytes [36]. In studies of albumin TET, binding of albumin to its receptor (gp60) was found to activate cSrc kinase and induce caveolin-1 Tyr14 phosphorylation. The resultant increase in endothelial albumin uptake was prevented by inhibition of protein tyrosine kinase [37] and by expression of dominant negative Src [38]. Recently, it has been reported that cSrc activation by a $\mathrm{Ca} 2+$ and nitric oxide-dependent mechanism stimulates caveolin-1Tyr14 phosphorylation in response to albumin stimulation in human umbilical vein endothelial cells [39]. Moreover, EM immunocytochemistry has shown that increased vascular endothelial Tyr 14 caveolin-1 phosphorylation after inhibition of protein tyrosine phosphatase induces caveolar vesicles moving away from the cell surface into the cytoplasma [40]. Very recently, we have demonstrated that insulin stimulates caveolin-1 Tyr14 phosphorylation through activating cSrc during vascular endothelial insulin uptake, and this insulin-stimulated Tyr14 caveolin-1 phosphorylation is insulin receptor or its activity-dependent [19]. Inhibition of insulinstimulated Tyr14 caveolin-1 phosphorylation by either inhibition of cSrc activity or mutation of caveolin-1 tyrosine 14 to phenylalanine significantly inhibits endothelial insulin uptake [19]. These data strongly support the important role of Tyr14 caveolin-1 phosphorylation in the regulation of endothelial caveolae-mediated insulin transport. Although the exact mechanism by which Tyr14 caveolin-1phosphorylation regulates insulin TET is not clear, Srcmediated Tyr14 caveolin-1 phosphorylation has been shown to affect the caveolin-1 association with and the caveolae targeting of both 
signaling molecules (e.g. eNOS, dynamin-2) and kinases such as active cSrc,which is required by assembling of endothelial transcytotic machinery [39,41,42]. The increased interaction of Tyr14 phosphorylated caveolin-1 and eNOS mediated by cSrc activation is determined by Tyr14 phosphorylation of caveolin-1 but not by the phosphorylation of eNOS at Ser1177 [39] suggesting that Tyr14 phosphorylated caveolin-1 may serve as a specific form of scaffold to recruit and organize multiple molecular components of endothelial transcytotic machinery in caveolae [19].

Taken together, current evidence strongly indicates that insulinstimulated Tyr14 caveolin-1 phosphorylation is a critical step linking insulin signaling and insulin TET. Given the critical role of insulin TET in regulation of systemic/muscle insulin action, further studies are warranted to uncover the detailed regulatory mechanisms of this process. New discoveries may suggest new intervention sites to mitigate systemic/muscle insulin resistance. These discoveries will also suggest potential translational therapies for metabolic diseases through manipulating these pathways.

\section{References}

1. Yang YJ, Hope ID, Ader M, Bergman RN (1989) Insulin transport across capillaries is rate limiting for insulin action in dogs. J Clin Invest 84 : 1620-1628.

2. Castillo C, Bogardus C, Bergman R, Thuillez P, Lillioja S (1994) Interstitial insulin concentrations determine glucose uptake rates but not insulin resistance in lean and obese men. J Clin Invest 93: 10-16.

3. Yang YJ, Hope I, Ader M, Poulin RA, Bergman RN (1992) Dose-response relationship between lymph insulin and glucose uptake reveals enhanced insulin sensitivity of peripheral tissues. Diabetes 41: 241-253.

4. Sjöstrand M, Holmäng A, Lönnroth P (1999) Measurement of interstitial insulin in human muscle. Am J Physiol 276: E151-154.

5. Sjöstrand M, Holmäng A, Strindberg L, Lönnroth P (2000) Estimations of muscle interstitial insulin, glucose, and lactate in type 2 diabetic subjects. Am J PhysiolEndocrinolMetab 279: E1097-1103.

6. Gudbjörnsdóttir S, Sjöstrand M, Strindberg L, Wahren J, Lönnroth P (2003) Direct measurements of the permeability surface area for insulin and glucose in human skeletal muscle. J ClinEndocrinolMetab 88 : 4559-4564.

7. Yang YJ, Hope ID, Ader M, Bergman RN (1994) Importance of transcapillary insulin transport to dynamics of insulin action after intravenous glucose. Am J Physiol 266: E17-25.

8. Miles PD, Li S, Hart M, Romeo O, Cheng J, et al. (1998) Mechanisms of insulin resistance in experimental hyperinsulinemic dogs. J Clin Invest 101: 202-211

9. Sjöstrand M, Gudbjörnsdottir S, Holmäng A, Lönn L, Strindberg L, et al. (2002) Delayed transcapillary transport of insulin to muscle interstitial fluid in obese subjects. Diabetes 51: 2742-2748.

10. King GL, Johnson SM (1985) Receptor-mediated transport of insulin across endothelial cells. Science 227: 1583-1586.

11. Bendayan M, Rasio EA (1996) Transport of insulin and albumin by the microvascular endothelium of the rete mirabile. J Cell Sci 109 : 1857-1864.

12. Wang AX, Wang H, Barrett E (2010) JDynamin-2 is Critical for Vascular Endothelial Insulin Uptake. Diabetes 59 Supplement 1, A380.

13. Wang H, Wang AX, Barrett EJ (2011) Caveolin-1 is required for vascular endothelial insulin uptake. Am J Physiol Endocrinol Metab 300: 134-144.

14. Wang H, Wang AX, Barrett EJ (2012) Insulin-induced endothelial cell cortical actin filament remodeling: a requirement for trans-endothelial insulin transport. MolEndocrinol 26: 1327-1338.

15. Wang H, Wang AX, Liu Z, Barrett EJ (2008) Insulin signaling stimulates insulin transport by bovine aortic endothelial cells. Diabetes 57: 540-547.
16. Wang H, Wang AX, Aylor K, Barrett EJ (2013) Nitric oxide directly promotes vascular endothelial insulin transport. Diabetes 62: 4030-4042.

17. Wang H, Wang AX, Liu Z, Chai W, Barrett EJ(2009) The trafficking/ interaction of eNOS and caveolin-1 induced by insulin modulates endothelial nitric oxide production. MolEndocrinol 23: 1613-1623.

18. Wang H, Liu Z, Li G, Barrett EJ (2006) The vascular endothelial cell mediates insulin transport into skeletal muscle. Am J PhysiolEndocrinolMetab 291: E323-332.

19. Wang H, Wang AX, Aylor K, Barrett EJ (2015) Caveolin-1 phosphorylation regulates vascular endothelial insulin uptake and is impaired by insulin resistance in rats. Diabetologia.

20. Simionescu M, Simionescu N, Palade GE (1974) Morphometric data on the endothelium of blood capillaries. J Cell Biol 60: 128-152.

21. Predescu D, Palade GE (1993) Plasmalemmal vesicles represent the large pore system of continuous microvascular endothelium. Am J Physiol 265: H725-733.

22. Drab M, Verkade P, Elger M, Kasper M, Lohn M, et al. (2001) Loss of caveolae, vascular dysfunction, and pulmonary defects in caveolin-1 gene-disrupted mice. Science 293: 2449-2452.

23. Miyawaki-Shimizu K, Predescu D, Shimizu J, Broman M, Predescu S, et al. (2006) siRNA-induced caveolin-1 knockdown in mice increases lung vascular permeability via the junctional pathway.Am J Physiol Lung Cell MolPhysiol 290: L405-413.

24. Fra AM, Williamson E, Simons K, Parton RG (1995) De novo formation of caveolae in lymphocytes by expression of VIP21-caveolin. ProcNatlAcadSci U S A 92: 8655-8659.

25. Oh P, Borgström P, Witkiewicz H, Li Y, Borgström BJ, et al. (2007) Live dynamic imaging of caveolae pumping targeted antibody rapidly and specifically across endothelium in the lung. Nat Biotechnol 25: 327-337.

26. Montesano R, Roth J, Robert A, Orci L (1982) Non-coated membrane invaginations are involved in binding and internalization of cholera and tetanus toxins. Nature 296: 651-653.

27. Pelkmans L, Zerial M (2005) Kinase-regulated quantal assemblies and kiss-and-run recycling of caveolae. Nature 436: 128-133.

28. Schubert W, Frank PG, Razani B, Park DS, Chow CW, et al. (2001) Caveolae-deficient endothelial cells show defects in the uptake and transport of albumin in vivo. J BiolChem 276: 48619-48622.

29. Schubert W, Frank PG, Woodman SE, Hyogo H, Cohen DE, et al (2002) Microvascularhyperpermeability in caveolin-1 (-/-) knock-out mice. Treatment with a specific nitric-oxide synthase inhibitor, L-name, restores normal microvascular permeability in Cav-1 null mice. J BiolChem 277: 40091-40098.

30. Foti M, Porcheron G, Fournier M, Maeder C, Carpentier JL (2007) The neck of caveolae is a distinct plasma membrane subdomain that concentrates insulin receptors in 3T3-L1 adipocytes. ProcNatlAcadSci U S A Epub 104: 1242-1247.

31. Okamoto T, Schlegel A, Scherer PE, Lisanti MP (1998) Caveolins, a family of scaffolding proteins for organizing "preassembled signaling complexes" at the plasma membrane. J BiolChem 273: 5419-5422.

32. Glenney JR Jr (1989) Tyrosine phosphorylation of a $22-\mathrm{kDa}$ protein is correlated with transformation by Rous sarcoma virus. J BiolChem 264: 20163-20166.

33. Rothberg KG, Heuser JE, Donzell WC, Ying YS, Glenney JR, et al. (1992) Caveolin, a protein component of caveolae membrane coats. Cell 68: 673-682.

34. Li S, Seitz R, Lisanti MP (1996) Phosphorylation of caveolin by src tyrosine kinases. The alpha-isoform of caveolin is selectively phosphorylated by v-Src in vivo. J BiolChem 271: 3863-3868.

35. Lee H, Volonte D, Galbiati F, Iyengar P, Lublin DM, et al. (2000) Constitutive and growth factor-regulated phosphorylation of caveolin-1 occurs at the same site (Tyr-14) in vivo: identification of a c-Src/Cav-1/ Grb7 signaling cassette. MolEndocrinol 14: 1750-1775.

36. Kimura A, Mora S, Shigematsu S, Pessin JE, Saltiel AR (2002) The insulin receptor catalyzes the tyrosine phosphorylation of caveolin-1. J BiolChem 277: 30153-30158. 
Citation: Wang H (2015) Pull the Trigger, it Fires: The Critical Role of Insulin-Stimulated Caveolin-1 Tyrosine 14 Phosphorylation in Regulation of Insulin Trans-Endothelial Transport. J Metabolic Synd 4: e114. doi:10.4172/2167-0943.1000e114

Page 3 of 3

37. Tiruppathi C, Song W, Bergenfeldt M, Sass P, Malik AB (1997) Gp60 activation mediates albumin transcytosis in endothelial cells by tyrosine kinase-dependent pathway. J BiolChem 272: 25968-25975.

38. Minshall RD, Tiruppathi C, Vogel SM, Niles WD, Gilchrist A, et al. (2000) Endothelial cell-surface gp60 activates vesicle formation and trafficking via G(i)-coupled Src kinase signaling pathway. J Cell Biol 150: 1057-1070

39. Chen Z, Bakhshi FR, Shajahan AN, Sharma T, Mao M, et al. (2012) Nitric oxide-dependent Src activation and resultant caveolin-1 phosphorylation promote eNOS/caveolin-1 binding and eNOS inhibition. MolBiol Cell 23: $1388-1398$.
40. Aoki T, Nomura R, Fujimoto T (1999) Tyrosine phosphorylation of caveolin-1 in the endothelium. Exp Cell Res 253: 629-636.

41. Shajahan AN, Timblin BK, Sandoval R, Tiruppathi C, Malik AB, et al. (2004) Role of Src-induced dynamin-2 phosphorylation in caveolaemediated endocytosis in endothelial cells. J BiolChem 279: 20392-20400.

42. Gottlieb-Abraham E, Shvartsman DE, Donaldson JC, Ehrlich M, Gutman O, et al. (2013) Src-mediated caveolin-1 phosphorylation affects the targeting of active Src to specific membrane sites. MolBiol Cell 24: 3881-3895. 